
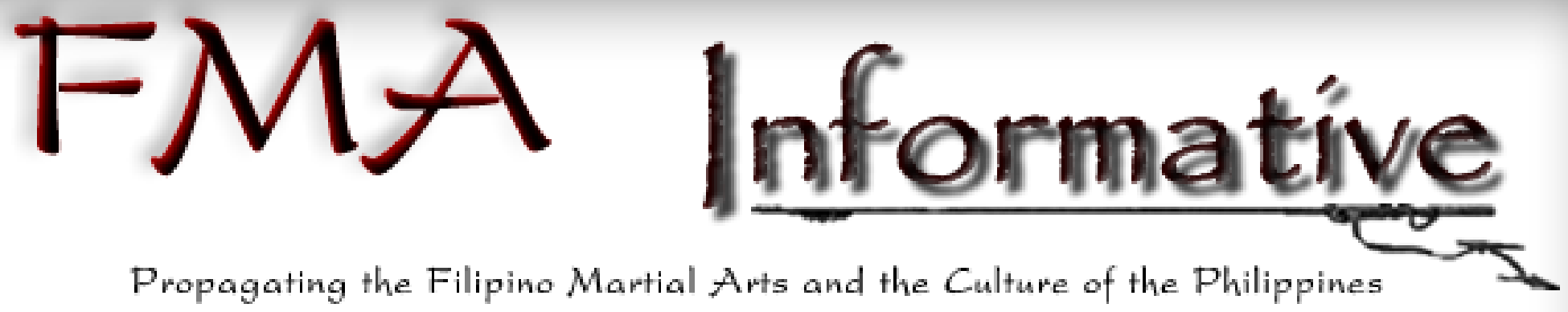

Propagating the Filipino Martial Arts and the Culture of the Philippines

Informative Issue No. 187 2015
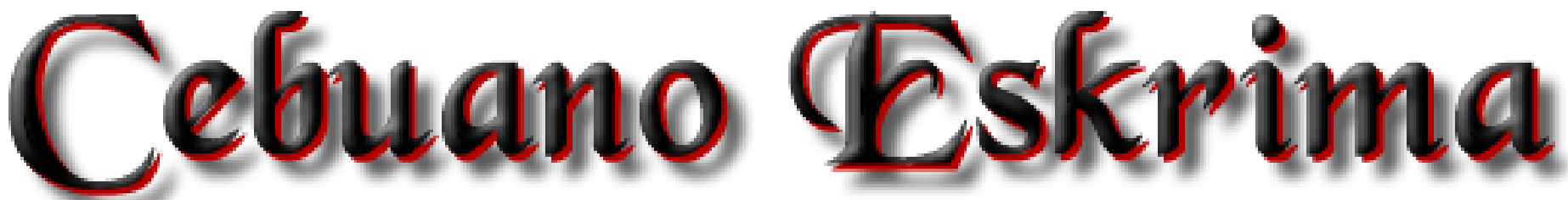

Beyond the Myth

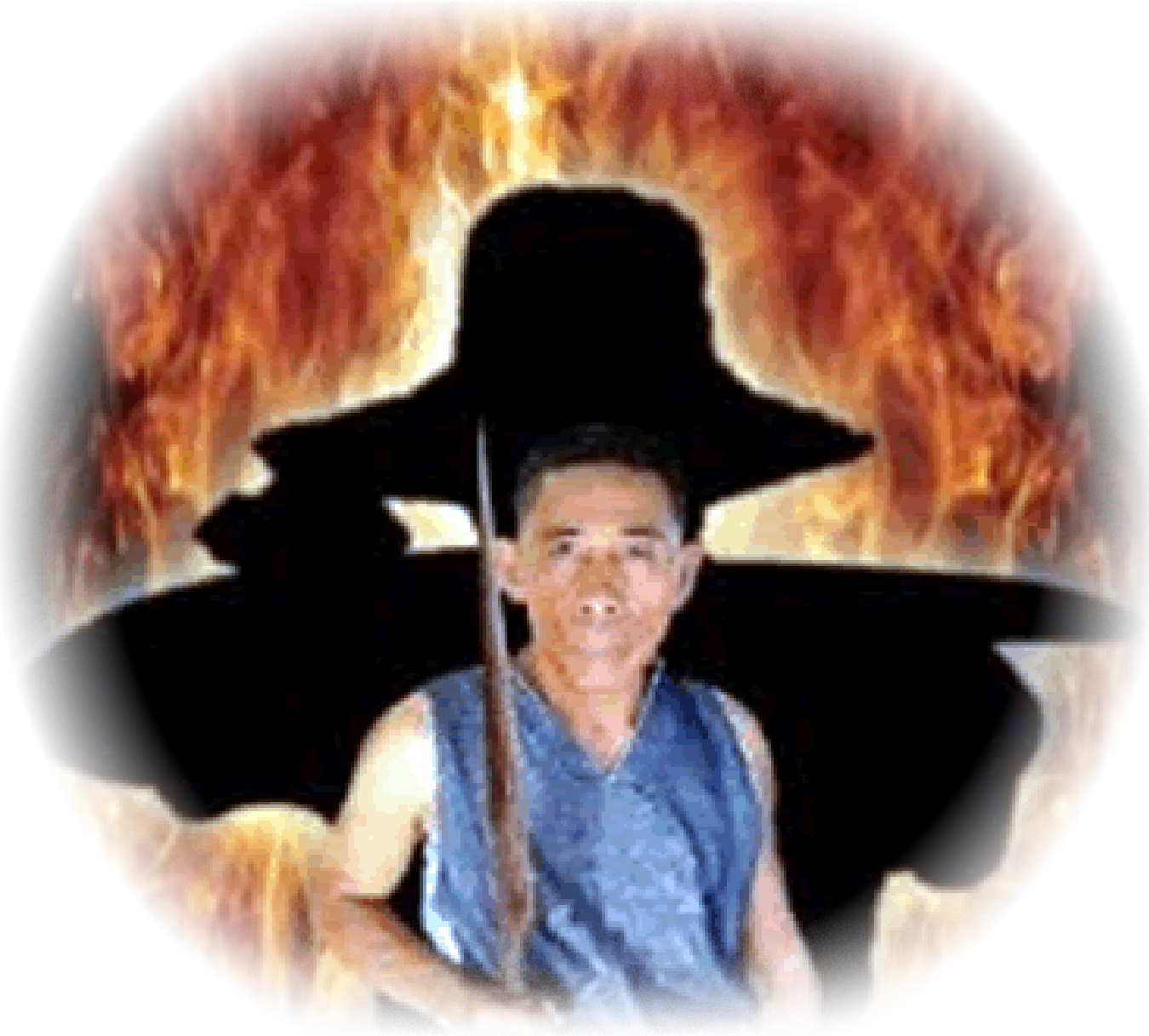

Celestino C. Macachor and $\mathcal{N}$ ed R. Nepangue, M.D. 
New Theories on the Origins of Eskrima - Celestino Macachor

Interview with Celestino C. Macachor

Ned Nepangue Points out Some Facts on Kali

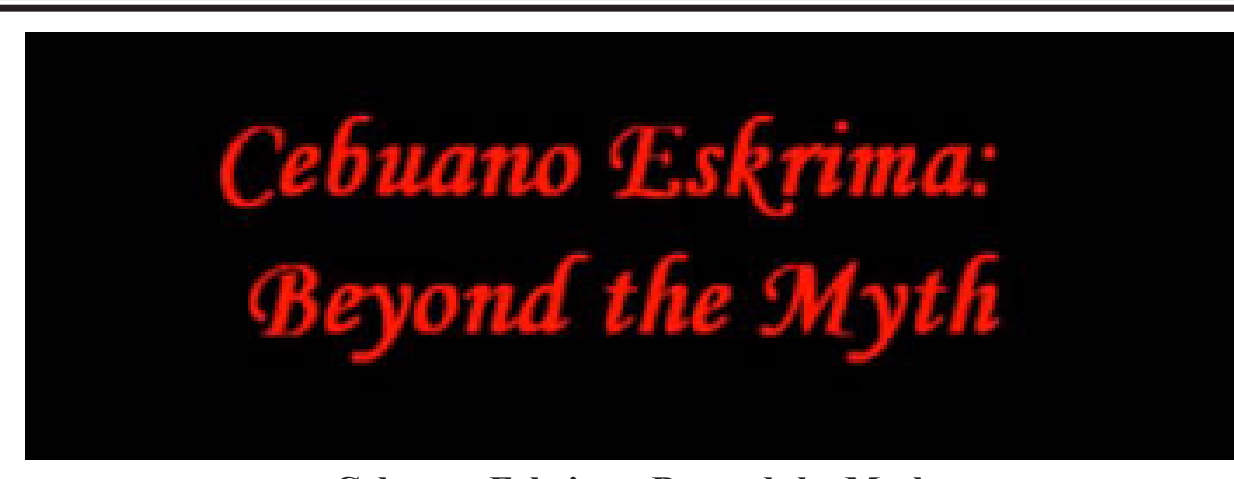

Cebuano Eskrima: Beyond the Myth

(a video digest)

Click Here

A short video synopsis of the book Cebuano Eskrima: Beyond the Myth written by Dr. Ned R.A. Nepangue and Celestino C. Macachor.

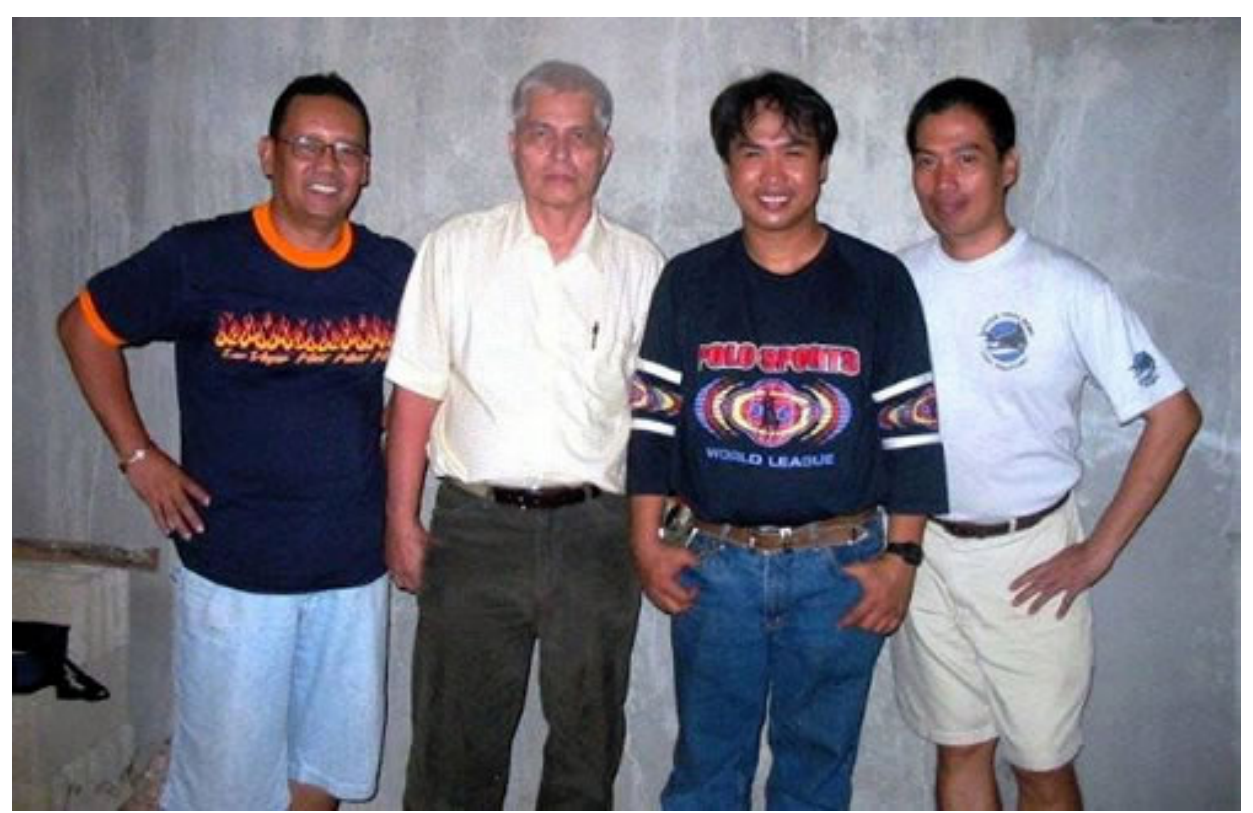

Celestino C. Macachor - Eric Olavides - Lito Gabuya - Ned R. Nepangue

Each issue features practitioners of martial arts and other internal arts, other features include historical, theoretical and technical articles; reflections, Filipino martial arts, healing arts, the culture of the Philippines and other related subjects.

The authors, publisher and owner of this online magazine are not responsible for any injury, which may result from the instructions contained in this online magazine. Before embarking on any of the physical activates described the magazine, the reader should consult his or her physician for advice regarding their individual suitability for performing such activity.

The ideas and opinions expressed in the FMA Informative online magazine are those of the authors or instructors being interviewed and are not necessarily the views of the publisher, editor or owner of the FMA Informative. The articles are the property of the author's that wrote them and cannot be used without the permission of the author.

The FMA Informative is for the promulgation and promotion of the Filipino martial arts and the Culture of the Philippines. NO issue can be printed and Sold for Monies, without the express permission of the Owner and Publisher of the FMA Informative.
The FMA Informative would like to personally thank Mr. Celestino Macachor, for all the information and assistance that was provided for this issue.

The FMA Informative representative met Ned Nepangue in 2008 while in Manila, Philippines and there was just a little conversation about a few things, due to time restraints. Mr. Nepangue was a very busy person researching some new material for the future.

However the FMA Informative while visiting the Philippines in March of 2015 and in Cebu, was very fortunate to get to meet and talk with Celestino Macachor. It was an honor to finally meet with the co-author of Cebuano Eskrima: Beyond the Myth.

To start the issue from Mr. Macachor the article "New Theories on the Origins of Eskrima". Which was published in Rapid Journal who granted the FMA Informative permission to re-publish it.

Next the FMA Informative representative was able to talk and discuss somethings with Mr. Macachor on the subject of the Filipino martial arts about the past, present and future. And also to ask a few questions about the book "Cebuano Eskrima: Beyond the Myth."

The final article is by Ned Nepangue which points out some facts on Kali.

What is really misunderstood and repugnant for the Cebuano martial artists, is the way throughout the world it is believed that the Filipino martial arts is basically of a Moro origin. That is far from the truth

The book "Cebuano Eskrima: Beyond the Myth" - authored by Ned R. Nepangue, M.D. and Celestino C. Macachor is a must have book, if interested or wanting to know about the Filipino martial arts. Basically about Cebuano Eskrima it takes away a lot of fictional stories and brings facts to the table.

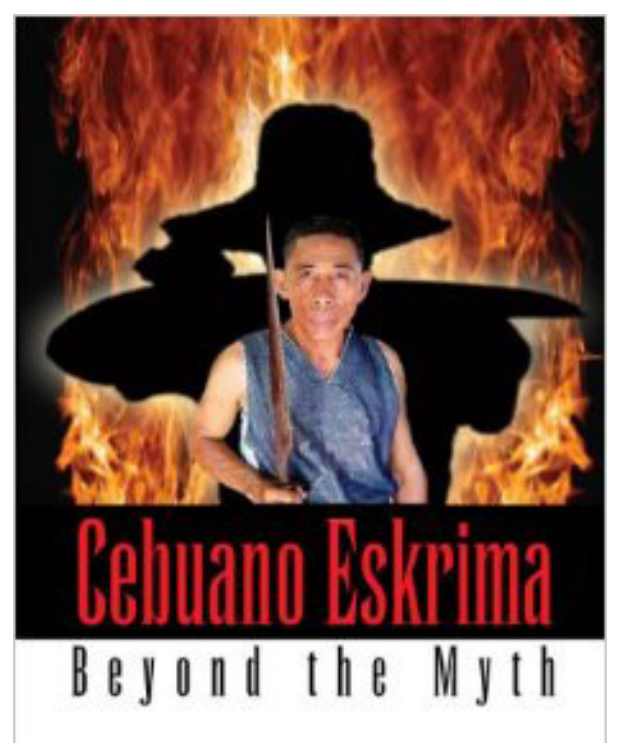

Nell R. Nepannugu, M.D. and Celestino C. Macachor

To Order Visit:

Xibris - Click Here

Amazon.com - Click Here

Barnes \& Noble - Click Here

AbeBooks.com - Click Here

BAM Books - Click Here

Rakuten.com - Click Here
Cebuano Eskrima: Beyond the Myth boldly unravels with compelling and provocative hypothesis on the Hispanic origins of the Filipino Martial Arts known as eskrima, arnis and estokada.

The authors present prima facie evidence on the fraud of the supposedly precursor art called kali.

A more plausible theory on the origins of eskrima are presented in startling detail from its early beginnings as a defense against Moro pirates and slave traders and its later fusion with Spanish fencing through the Jesuit warrior priests during the pivotal years 1635-1644, the height of Spanish rapier fencing in Europe during the Renaissance.

It also presents a comprehensive chronology on the development of eskrima in Cebu, a meticulous commentary of Cebuano pioneers and innovators of eskrima and elucidates the pre-eminence of Visayans in the art of eskrima / arnis / estokada.

As both authors are practitioners of this martial art, technicalities in eskrima never before detailed in other materials on the subject are carefully discussed in the book. 
In 2001 Celestino Macachor submitted his article, "New Theories on the Origins of Eskrima," to the Rapid Journal magazine, a magazine that was published in the Philippines.

Mr. Macachor article which was published in three parts, in the Rapid Journal a Filipino magazine for (Research and Propagation for Internal Arts Development), which came out in the following issues Volume 6 Number. 2 through Volume 6 Number 4

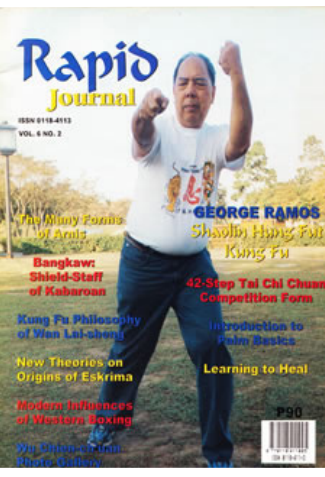

Vol6 No2

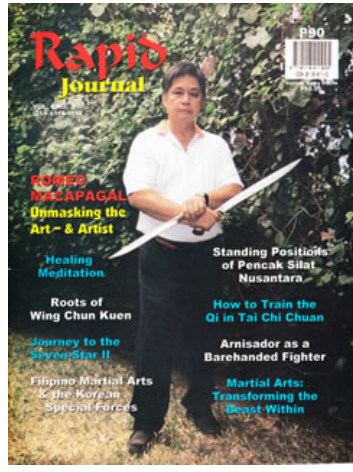

Vol6 No3

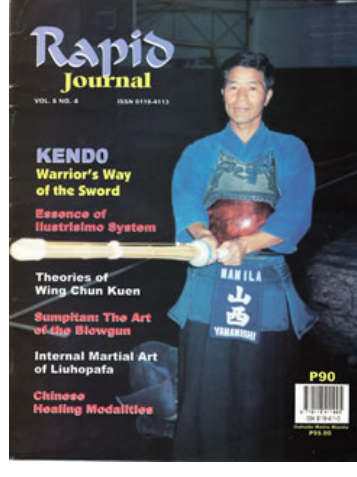

Vol6 No4

In part one Mr. Macachor presented his new theories on the origins of Eskrima which he claimed began with the conquest of the Spanish conquistadors in the Philippines during the 16th century.

In part two was a continuation of the saga on the history of Eskrima according to the research of the long time Arnis practitioner.

And finally part three and the final installment of the origin of Eskrima, which also mentions the important contributions of Spanish fencers to the art of Filipino Eskrima.

Here are parts of "New Theories on the Origins of Eskrima."

Note: To get the full story you can order the issues from the Rapid Journal, ordering information will be at the end of this article. Even the though the Rapid Journal is no longer in circulation the issues that were published are still available.

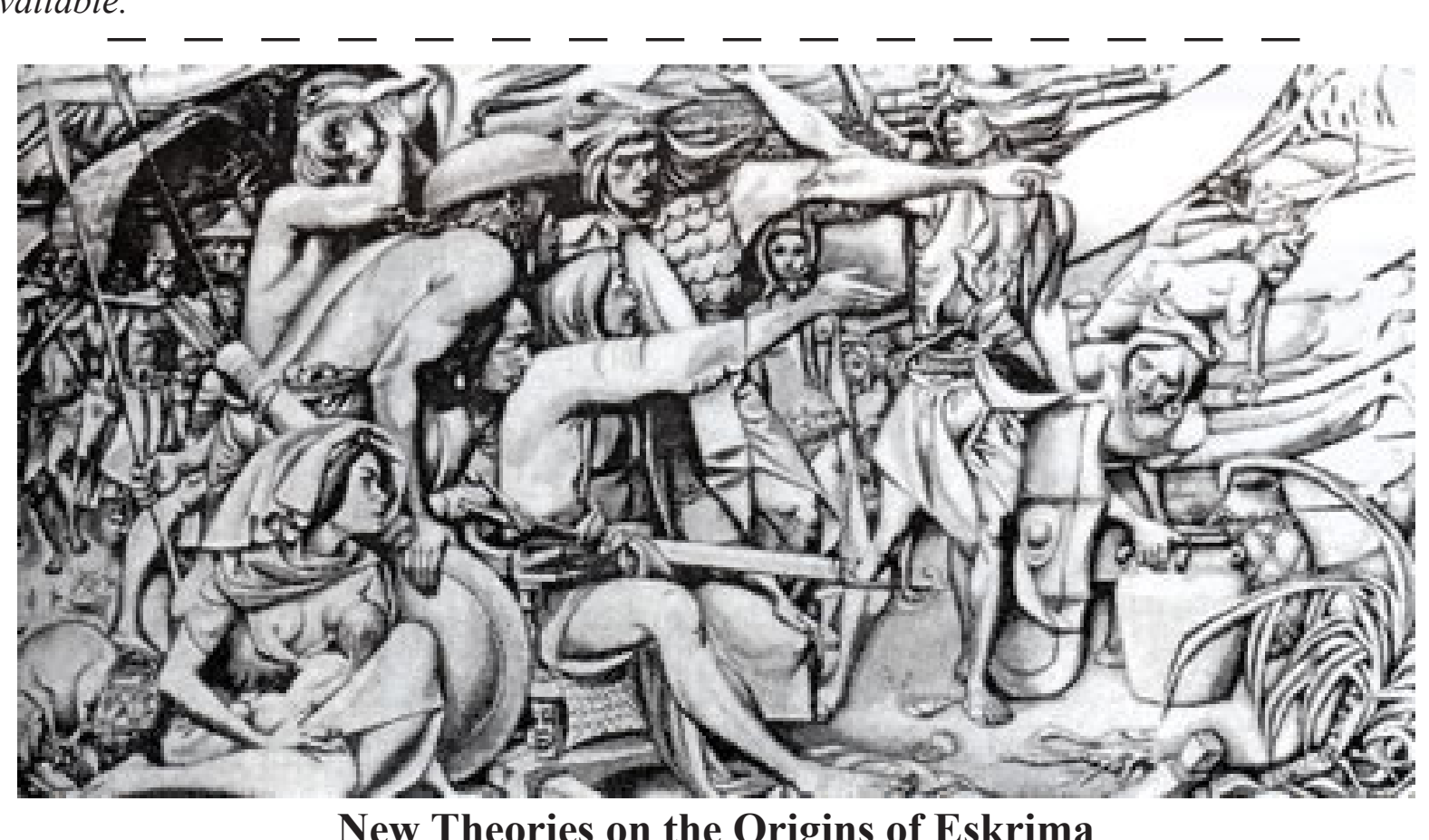

New Theories on the Origins of Eskrima

Regional ethnic pride seems to be the biggest obstacle in acquiring an unbiased historically correct account on the origins and evolution of Eskrima. The Ilonggos in West Visayas insist on the story of the ten Datus of Borneo that is widely believed to have brought with them an ancient form of bladed combat known as Kali. Congruent to the theory on Kali as the progenitor of Eskrima / Arnis are the hoaxes and fabrications on the Code of Maragtas and Kalantiaw. In his article Maragtas and Kalantiaw - History, Legend or Fraud?, Paul Morrow wrote:

"How do historians know about events which, according to them, occurred before there were Spaniards in the Philippines while there are almost no known authentic written documents from that era? Much of what we know about the pre-Hispanic era came to us through legends. These are stories that were not written but were spoken by each generation to the following generation. Legends change with each telling because often the teller's memory is weak or mistaken- or the teller just wants to make additions to the story to spice it up. Legends are usually nothing more than stories about the creation of the world, the first man and wom see that they are not meant to be regarded as fact. However, there are some legends which do contain a kernel of truth."

There is no truth to the stoy of the ten datus of Borneo. Thi was proven a fraud in a research made in 1968 by historian William Henry Scott that exposed author Jose Marco's fabrication story of supposed dis Maras. Scovt further revede Maragtas. Scott further revealed i his book Pre-Hispanic Source Materials for the Study of Philippine History.

“Jose E. Marco's contributions to Philippine historiography appear to be deliberate fabrications with no historic validity. There is therefore no present evidence that any Filipino ruler by the name of Kalantiaw ever existed or that the Kalantiaw penal code is any older than 1914."

Unsettling as it may be for some Filipino ethnic group, but with the advent of information revolution, as quickly as it is to spread lies and fabrications it is also as quick to debunk them ith serious hard work, with serious hard work, patience, methodical research and a passion for historical accuracy. Such is the story of the First Mass in the Island of Limasawa, Leyte that until the overthrow of Marcos and to appease her flamboyant First Lady a native of Leyte, was tak- en as irrefutable historical fact ritten in textbooks and taught in all our schools. There is now an archaeological/docmentary evidence presented by credible historians, anthropologist and archaeologists of Agusan del Norte that proves the First Mass was in fact celebrated in Masau present day Butuan City.

Like the Limasawa story, Philippine history is replete with fake stories and fantasies concocted by self-serving politicians especially the ruling elite of Manila and other vested interest groups. This will go on while there are still scams like the textbook bribery scandal in 1998 involving Mary Ann Maslog.

Finding physical /archaeological evidence to determine the exact origins of the Filipino Martial Arts is a very remote possibility, nevertheless, we can collate a wealth of information from the academe and other reliable sources to piece together our theory that:

Theory 1.

Contrary to popular belief that it is pre-Hispanic, Eskrima / Arnis / Estokada is a relatively new Martial Art and did not precede the arrival of the Spanish conquistadors and developed mainly in the coastal towns of Cebu, Siquijor, Bohol, Negros, Leyte, Panay and coastal towns of Luzon like Pangasinan, and Pampanga that became a favorite predatory ground for marauding Moro pirates. From a retreating and defensive mode, the early $\mathrm{Vi}$ sayans shifteds relied on Cottas to more aggressive offensive tactics.

Extracted from Cebu in Legend and History by Evangeline Lavilles de Paula and Angels in Stone by Fr. Pedro G. Galende, OSA are these stories:

1.1 Moalboal - Southwest Cebu Coast

This story is probably the first historical account on the use of canes and Latin Oracion against Moro Invaders and the significant contribution of Bohol style Eskrima to the Cebuano martial arts. Again, I would like to reite ate that the writers belong to the mainstream academe and were in no way involved in the research of Filipino martial arts history.

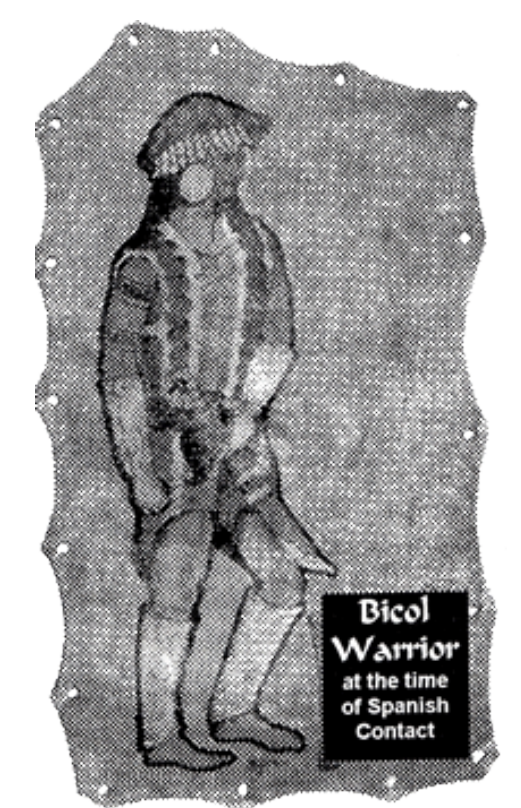

"Oral tradition relates that $\mathrm{Bo}$ holano pioneers founded the town of Moalboal. A substantiation of this contention is that its leading families - the Gadors, Cabarons, Bableras, Redobles and many more - came from Bohol. Another fact is that many residents, especially the older ones, still speak with Boholano accent.

The first Boholano to settle in the town was Laurente Sabanal. He was captured by the Spaniards in Bohol for having killed a guardia civil. But he later escaped on a rowboat to Cebu. He chos Moalboal as his new home, having 
found the land fertile and the sea abundant with fish. He lived alone for a while, but he later returned to his native town and brought back with him his family and some relatives to immigrate to hi. new-found home. Expectedly, he became the ruler of the settlement. The Muslims also directed their raids at Moalboal, being already a prosperous settlement. But led by Sabanal, the inhabitants successfully repulsed the invaders. They attributed their victory to Sabanal's oracion. When he died, it is said that he was buried by the shore marked by his magic cane. To this day, a part of it could still be seen. In his honor, the people named a street along the shore."

1.2 Spanish Period - Bantayan Islands

Kinatarcan Island, which belongs to the Bantayan group of Islands, is the birthplace of GM

Floro Villabrille and GM Antonio Ilustrisimo. A colleague Juris Fernandez who comes from Doong Isand told us about his Great Grandfather Tata Lucio Pastor who is one of the longest living Eskrimador of the island. Tata Lucio Pasto who lived up to 106 years old used bakhaw a fire hardened wood cut from mangroves as fighting stick. The lineage of Tata Lucio Pastor's Eskrima is untraceable but the fact remains that his Eskrima is indigenous to the island of Doong and that it was probably develope to repulse superior weaponry and martial skills.

"The Parish of Bantayan was then under the direct control and supervision of the Archdiocese of Manila. Fr. de Ocampos then, built a church made of nipa and bamboo. This church was put on torch by the Moro raiders in 1600, when according to Blair and Robertson, some 800 Bantavanons were take as captive and sold as slaves to rich Mindanao Muslims. A second church was again erected and was gain put on fire by the marauding Moros.

The stone church as we now see is the third church erected. Construction of this church began on 1839 and completed on year 1863. It was Fr. Doroteo Andrada del Rosario who built this church with a tall belfry and tal walls that surround the plaza.

aware of the Moro attack built

several lookout towers. The

owers were located at Balwarte (Suba, Bantayan), Do-ong Island, Bantigue, Kabac, Daan Patio (Madridejos), Kaongkod (Madridejos), Tamiao, Ocoy (Sta. Fe), Cota (Sta. Fe) and Sulangan. Of these towers, only Bantigue and Sulangan have no ruins. To serve as signal of the incoming attack each tower is equipped with virso a canon like cylinder wherein explosives were set to make a very loud noise). If one tower sees the incoming invaders, they would make a signal. The next tower upon hearing the signal would in turn fire their virso and so with the next towers, a chain explosion is achieved until the signal would reach the town proper. The church bells would then ring the bells to warn the populace about the incoming attack and prepare for the said attack while the olds, woman and children are cloistered to the confines of the tall walls surrounding the church."

1.3 Pilar, Camotes Island, Cebu The next story from Lavilles de Paula recalls another vivid historical account on the use

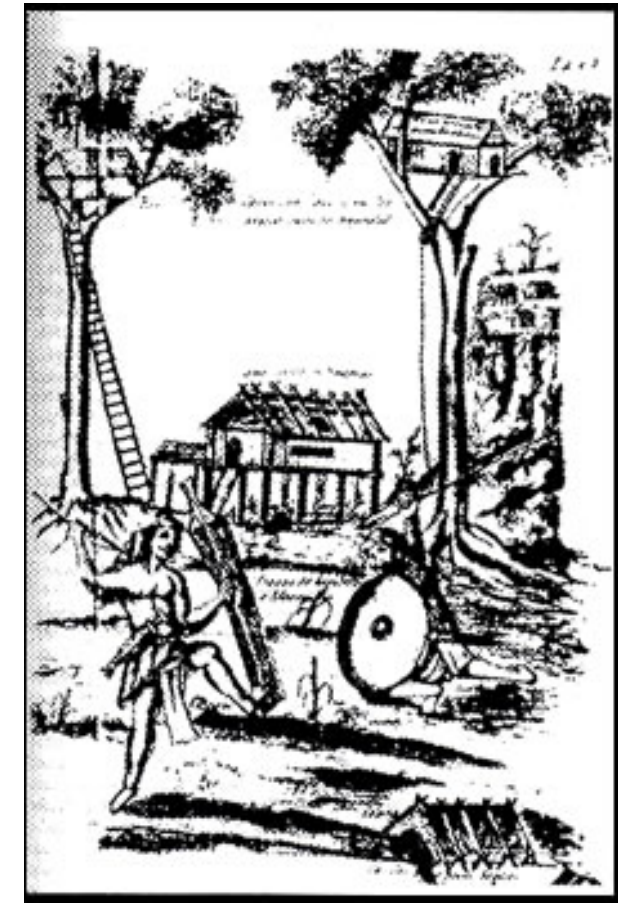

Visayan "tree houses" for defen From Alcina's 1688 Hisoria de laz islas e indios de las Bisayas

"In search for a better place to live in, a family from Cabalian Leyte Visayan sea to a

island and of a settlement in Cebu which grew into a town. Solferino Borinaga was attracted by the fertile soil and the rich fishing grounds of a place called Palawan. It was so named as there was a spring (Palawan in the dialect) in the area. He brought his wife Alejandra and son Martin. Since life seemed much better in their new home, Solferino went back to his native town and encouraged his relatives and friends to immigrate to Palawan. A group - about ten families - went with him. Together, they organized into a barrio.

The inhabitants - prosperous as they were - were objects of

forays by Moro pirates. Discovering the new colony, the Muslims would raid and seize properties, food, and even people. But Solferino Borinaga was an exceptional leader, not only good in organizin but an expert in the art of battle. Together with only a few men, the did not only defend their village successfully, but they also mounted offensive attacks on the veteran sea warriors, fighting them face to face. Surprisingly defeated, the Moros fled and never disturbed the village again.

News of unprecedented victory over the Moros spread and soon many went to Palawan to settle there permanently. It grew into a town and quite naturally, it was Solferino Borinaga who was its first capitan."

Theory 2.

The Province of Cebu stretching from Bantayan Islands in the North to Santander in the South became the focal point in the development of Eskrima and that its development and tactical use outlived the Moro raiders. The Art of Eskrima was also effective against Spanish and American colonizers and also against the Japanese invaders. More heroic stories of the coastal towns in Cebu from Evangeline Lavilles de Paula's

book: Cebu in Legend and History:

\section{Theory 4.}

Arnis in Luzon particulary the province of Pampanga blossomed at the same time as Eskrim in the Visayas during the administration of Governor General Sebastian Hurtado de Corcuera.

4.1 The Filipino Martial Arts that we know today was a deadly chemistry of Macabebe, Cebuano, Ilonggo and other Visayan Martial Arts. These diverse ethnic groups became brothers in arms and their meticulous recruitment by the Spaniards was intended to match the skills of the Moro warriors. The only bridge to a cultural and language barrier among this mixture of Visayans and Capampangans was their mutual hatred of Moros and the cross-pollination of combat skills. Chapter 9 of Vic Hurley's Swiss of the Kris recalls accurately the recruitment of Pampango, Cebuano and Ilonggo conscripts during the administration of Governor General Sebastian Hurtado de Corcuera to fight against the Moros of Sulu. Hurley credited Corcuera as the most successful Governor Genera during the Spanish colonial period to have successfully contained the Moros of Sulu. Here are some excerpts of Chapter 9 to support our theory:

"After due preparation, an expeditionary force under the command of Captain Juan de Chaves landed at Zamboanga on April 6, 1635.

There de Chaves founded the town of Bagumbayan, which was the

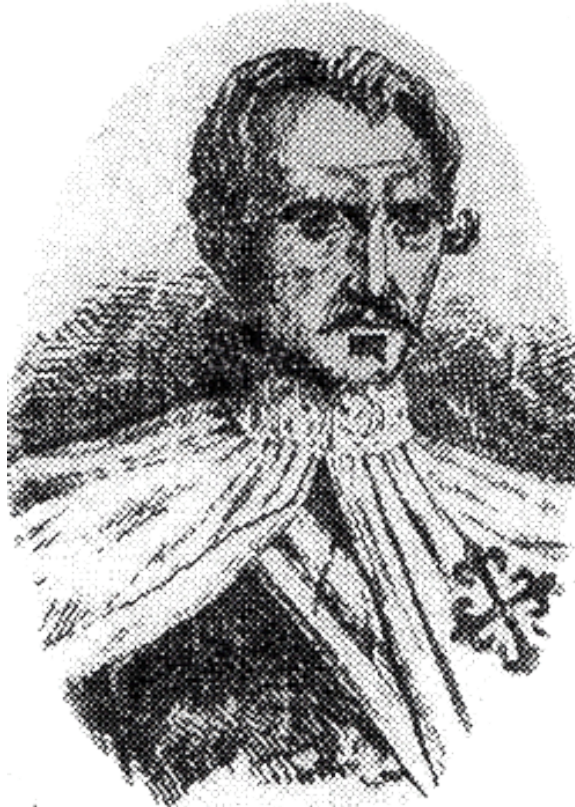

Governor General Sebastian Hurtado de Corcuera - was he the father of the Filipino martial arts? first name for Zamboanga, and from this station he soon reduced gan

After Captain de Chaves force of 300 well-armed Spaniards and 1000 Visayans had cleared the peninsula temporarily of hostile Moros, the construction of one of the finest forts in the East wi into execution. On June 23, 1635 the foundations of the grand fortress of Nuestra Senora del Pilar was laid by Father Vera, engineer of the Spanish army."

The year 1635 had witnessed the arrival in Manila of a very efficient Governor-General and a perfect soldier. The coming of Don Sebastian Hurtado de Corcuera marked a period of success for the Spanish arms which was not to be equaled again until the mighty soldier Juan Arolas arrived 250 years later.

$$
\text { Whatever Corcuera's emo- }
$$

tions as he gazed down the valley

to the horde of brown kris men

waiting to resist him, there can be no question as to his valor. At a flourish of a mailed fist, the Spanish plumes disappeared into the wave of Moros.

We are indebted to Father Crevas for an account of this campaign. From him we learn that Corcuera, with a squadron of small vessels and a dozen flat boats, entered the river, defying Correlat. "The forces which he had were five companies; his own of 150 men, those of Captain Nicholas Gonzalez and Lorenzo Orella de Ugalde of 100 men each; another company of sailors; another of Pampangos; all the rest were rabble and pioneers. The same day he reached the river, he entered, with seventy men, the court of Correlat, defended by 
As we consider the caliber of the men who opposed Corcuer that day, we wonder how he kept his small company from being overwhelmed. The Spaniards had arquebuses, but they were slow and laborious to reload. A great deal of the combat must have been hand-to-hand. Pitched to religiou fervor, a Moro was the equal to any Spaniard in hand-to-hand battle, and yet Corcuera survived to win a brilliant victory.

de Corcuera remains as one of the conspicuous figures of the Spanish conquest of Mindanao. He was

a perfect soldier. His reward for distinguished service in the field against the Moros was paralleled by the treatment Cortez and Balboa received at the hands of the Spanish crown.

During his term of office as Governor-General of the Philippines (1635-1644), he incurred the displeasure of the Friars, and upo being succeeded by Diego Fajardo, he was haled into court, fined 25,000 and thrown into prison for five years. He was finally released by a Royal Order and given the tardy award of Governor of the Canary Islands.

Ned Nepangue in a previous article wrote of the stick

fighting arts of Canary Islands and Venezuela that is closely similar in technical form to Eskrima / Arnis Who could have introduced stick fighting in the Canary Islands? From the historical facts above we can surmise that De Corcuera, during his administration of the Canary Islands could have brought along with him trusted alalays (cronies) that probably cross trained with native Filipinos during his Mindanao campaign.

4.2 From another source Complet Sinawali by Reynaldo Galang, he wrote:

"A royal decree in 1636 ordered the "pacification" of the island of Mindanao. Two large companies composed of mainly Pampangans and Visayans were part of the force led by Governor General Sebastian Hurtado de Corcuera. This force traveled aboard eleven large vessels with 760 Spanish infantrymen who were divided into a total of seven companies. Using Zamboanga as base, the troops underwent rigorous training with the advice and help of Datu Suksukan of Zamboanga and Datu Piatong of the Lutaos"

Chavacano the native dialect of the Zamboanguenos is a hodgepodge of bastardized Spanish, Cebuano, Yakan and Subanon dialects.

4.3 Even after the administration of Corcuera the Spanish authorities continued to employ Visayan mercenaries to exact revenge and kill as many Moros as they can with the promise of great rewards. Chapter 13 of Swish of the Kris details this account:

"A decree dated December 21, 1751, was signed by the Governor-General of Manila. It provided:

The extermination of the Moslems of Mindanao and Sulu with fire and sword and no quarter fo Moros of any age or either sex.

The fitting out of Visayan corsairs with authority to extinguish the foe; to accomplish the burning of all that was combustible.

-To destroy all crops; desolate all land; make Moro captives and recover Christian slaves.
- One fifth of the spoil taken from the Moros belong to the King.

- All Visayans engaged to be exempt from the payment of all tribute while engaged in the extermination of the Moros.

- Criminals who volunteer to the service to be granted full pardon for past offenses."

Given this historical

background on the animosity of Visayan Christians and Moros, it is easy to grasp how deep rooted the conflict in Mindan is unt today. The bloody war of attrition between the Barracudas (Moro fighters) and the Ilagas (Ilonggos) and the succeeding MNLF war of secession in the1970's displaced than a quarter of a million slims in Mindanao. Casualties from both sides also numbered to several hundred thousand.

4.4 The recruitment of Cebuanos continued until the 19th century. Chapter 15 Later Wars of Swish of the Kris, recalls graphically what motivated the Cebuanos to volunteer in a war against the Moros in the name of the King of Spain

"Indeed, matters reached such a state that before the end of the year warships were ordered out for another at regiments of infantry and a corp of artillery aided the gunboats. Included was a battalion of Cebuanoes (sic) who sought revenge for the Moro raids. The wives of the Cebuanoes(sic) emulated Lysistra ta in reverse. Every wife took an oath before Father Ibanez to deny forever their husbands all of their favors if the Cebuano men turned their backs to the Moros. In the battle of Jolo, Father Ibanez lost his life in the assault on a Moro cotta. The good Father tucked his cassock about his waist and plunged into the thickest of the battle. The Cebuanoes(sic) performed prodigies of valor and Jolo fell again. The seat of the Sultanate was removed across the island to Maybun, and the Moros paid regular visits to Jolo to slaughter the Spanish garrison which remained.

It is therefore not unthinkable that the Cebuano survivors veterans of this campaign later passed on their martial arts skills to the rest of Cebu and the Visayan Islands. The foregoing text also bolsters our theory on the active participation of Spanish priests in combat and their influence in the development of Eskrima. Lavilles de Paula in her narrative told of the same pat plunder in the towns of Sibonga Mandaue with its famous Bantaya sa Hari Tower, Carcar, Oslob,Nag a and Talisay. Practically all the 52 coastal municipalities of Cebu had a history of recurring Moro forays. Given this statistics and taking into account the brave Sri Vishayan ancestry of the Cebuanos, Ilonggos and Warays, we can deduce that a raw form of Martial Arts started to take shape in defense of their coastal communities. Later the Spanish a hories took vantage of the Martial skills of the native Cebuanos and their animo ity against the Moros during the Corcuera administration. And with the subsequent alliance with the

Pampangos and a more deadly and highly developed martial arts that we now call as Eskrima, Arnis, Estoque or Estokada later flourished.

4.5 From the Book The Philippine Islands, Chapter XV by Blair \& Robertson is a narrativ of Moro raids in Leyte, Bohol and Panay Islands:
That year of 1634 was so quiet and so barren of events worthy of remembrance that I shall not dwell long upon it; for there is nothing of which I have heard to detain me, unless it be the raid of the Mindanao enemy into the island of Leyte, and the depredations that they committed there with the license permitted to them in that there was no attempt made in Manila to check them.

On Sunday, December 3 ,

1634, the Mindanaos arrived with eighteen galleys at the village of Ogmuc, (Ormoc City) leaving

behind in that of Baybay the rest of the vessels, which they brought in their fleet. Fifty of our Indians went out to resist them, but being unable to fight so many, they gradually retired to a little fort. possessed by the village. They

thought that they would be able to resist the pirates there, being encouraged by their minister, Fathe Juan del Carpio, of the Society of Jesus; and they did so for some time, until the Moros, knowing that the church was higher than the fort, entered it and our men could not reach them with their shots. They planted three pieces in a convenient place at the church. in order to do great damage to those in the fort; and firing with out cessation, they did not allow our men to fire a shot through its loopholes and windows. Others of the enemy hastened by another side to gather bundles of thatch by uncovering the roofs of the houses; and by fastening together what wood and bamboo they could gather, and pushing this contriv ance toward the fort, they set it afire. The fire burned a quantity of rice and abaca (which is the hemp of this country), and many men were choked by the smoke.

The besieged, seeing that the fire had caught the timber-work [of the fort], and that they were being inevitably killed without any chance to defend themselves, displayed a signal for surrender, and in fact did so.

They were all captured; and a great contest arose among the enemy as to who ther Carpio as his captive. the cindano they had recourse to the Mindano captain, and he ordered that the father be killed. That they did very gladly, and beheaded him and carried his head back to present it as a spoil to their king. Cachil Corralat (Sultan Kudarat). The latter had charged them not to leave alive any religious or Spaniard, for so had he vowed to their false prophet Mahomet in an illness that he had had. They took the others captive, and sacked and burned all the village. From that place they sailed out and commit ted the same destruction in the villages of Soyor, Binan, Cabalian, Canamucan, and Baybay (Leyte Island). But they were so stoutly resisted in the village of Inibanga (Inabanga) in [the island of] Bohol, and in Dapitan (Mindanao), that they retired but little the gainers; for those Indians (Visayan Christian natives) are very valiant, and very different in valor from the other villages which the Mindanaos sacked. 
lages of Batan, Domayan, and Ma hanlur, and in those of Aclan and Bahay, where they captured many of our Indians, and burned the churches of the visita. The visitas are usually deserted, and have no houses to defend them; and those Camucones are very cowardly and very different from the Joloans and Mindanaos, who are valiant, and much more so the latter named. The Camucones entered by the river and bar of Batan, which is salt water, where a very grievous jest happened to two or three of their craft. The river of Batan has another river a short distance above the village road, which ends in a very wide and spacious sea, which they call "tinagongdagat," or "hidden sea," in which the inhabitants enjoy excellent fishing. With the ebb of the tide that spacious sea is left, almost dry, and then many kinds of shellfish are caught. such as oysters and crabs. The Camucones entered that sea, with the intention of lying in wait for some capture, but when they least expected it they found their craft on dry ground. An Indian who was gathering the aforesaid shellfish saw them; and, recognizing them to be piratical enemies by the style of their craft, went to the village and gave warning of them. Many of the inhabitants of Batan assembled, and, well armed, attacked the Camucones very courageously. They made a great slaughter of the pirates, and captured many of them and burned their craft. Some of the Camucones escaped through the mangrove plantations and swampy ground. They were captured next day, with the exception of those who had the luck to rejoin the boats of their companions-who repenting of their carelessness. returned to their lands, and did not
Here are more excerpt rom Evangeline Lavilles de Paula's book Cebu in History and Legend:

"Boljoon is one of the oldest towns in the South. And it is also the most quaint and picturesque. Its narrow coastal plains are bordered by cliffs and luxuriant hills which has a commanding view of Bohol Strait.

According to Marin Morales, the town was created in 1598. The parish was established a year late But this was disputed by Fr. Blanco, asserting that the parish was founded in 1600. The church of Boljoon was started by Fr. Manuel Cordero and completed by $F$ Julian Bermejo, who also built the convent that was finished in 1841. The convent is L-shaped like a monastery surrounded by walls and tile roof.

Boljoon church is a veritable showcase of old and intricate carvings and bass relief. It still has the Spanish churchyard beside it. According to Tamayo, of all Cebu's churches, the Boljoon church best gives one a sense of the Philippine colonial past. J.T Newman describes the church: It is relatively well preserved, except for its communion rail with ornate silverwork, which has been stolen. It is pseudo-baroque-rococo. Its tower is unusual because it is Islamic in is unusual becanse it is tslar character, it is square, rather than curved, making it look more like a fortress than anything. Its rectangular belfry, built in 1701, has fort windows used to show cannons to defend against Moro pirates. The sound of its silver bells reached Oslob and Alcoy. But in 1802, they were stolen by Muslim hordes led by Datu Orendain. Because of their weight, the Moro vinta sunk. Fray
Antonio Maglano, OSA, was the warrior-priest who led the Boljoon militiamen.

One of the parish priest who worked hard to repulse the Muslim pirates was Fr. Julian Ber mejo. A chain of watchtowers was constructed under his direction.

This chain ran along the shoreline from Punta Ta

Manhage. It was later extended up to Carcar, for a total length of 96 $\mathrm{kms}$. He built a large quadrangular house made of masonry and its walls were at least a meter thick; its four corners were reinforced with loopholes. The town speople called it dakung balay. The Governor-general, impressed, sent to the necessary artillery equipment for this fortress. Fr, Bermejo also installed a telegraphic system for the purpose of constant comm icaion anong town in communication among towns in cases of impending raids.

Old Boljoon had four

dependents: Mambaje, Ivisan, and Tanon. The first three were situated near the beach, while Tanon was perched high up in the mountains serving as an observation post for the marauding Moros."

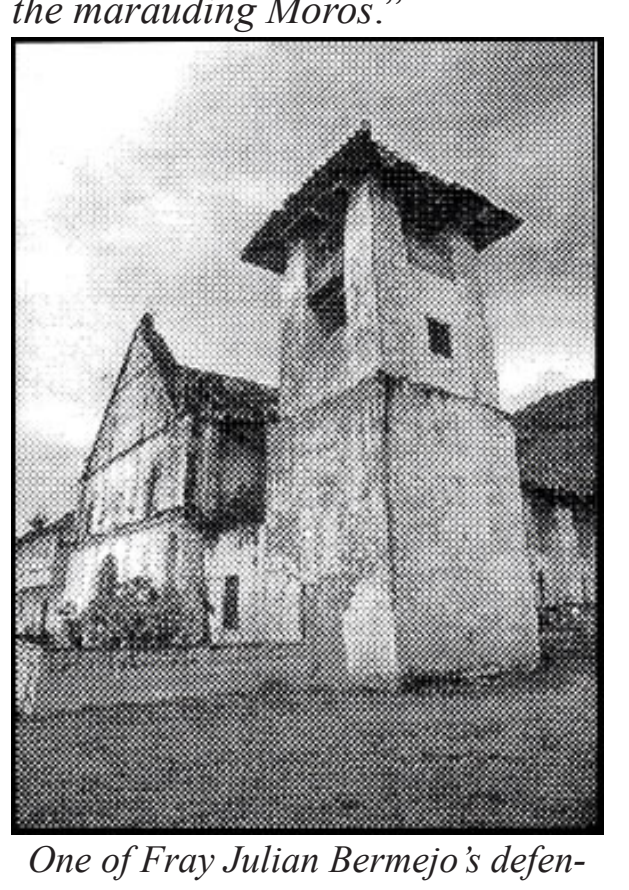

sive struct
5.2 Also from Chapter 11 of Swish of the Kris, Hurley gave credit to the bravery the Spanish priests:

The history of the Spanish occupation of the Philippines is filled with reference to the bravery of the militant priests of the Jesuit order. These ambidextrous missioners, Cross in left hand and Toledo blade in right, were in the first wave of every attack on the Moros."

The pattern of Moro raids from the shores of Bantayan Islands, Cebu, Antique, Iloilo, Leyte, Dumaguete to Pampanga matched perfectly with the dominance of these coastal provinces in today's Filipino Martial Arts of Eskrima, Arnis, and Estokada. Like the Big Bang Theory, the Filipino Martial Arts exploded in the years 1635-1644 during the term of Governor General Sebastion Hurtado de Corcuera, the military genius that pitted the best warriors of the Visayas and Luzon against the fearless Moros of Sulu. The dominant Fiipino martial arts organizations worldwide that originated from these once fertile Moro hunting grounds are Doce Pares, Kali Ilustrisimo, Pekiti-Tirsia and Giron Arnis Escrima. There are also several dozens of obscure styles that have taken root from hese provinces like, Bergonia Style, Toledo-Collado(Pangasia -once part of Pampanga province), Moro-moro (either Samar or Bohol orgins), Cadena de Mano (probably Panay), Abanico de

Vertical (West Cebu), Bohol style, Tapado (Negros) to name a few. It is foolhardy to assume hat a single ethnic group invented he Filipino Martial Arts, but what is obvious here however, is the Leon Kilat dominance of the Cebuanos and llonggos in the art of combat due to the vulnerability and proximity of their coastlines to the fast parao of Moro tives in these coastal areas had no pir to protect their territorities, women, children, culture and their newfound religion. The Moro attacks on the Cebu, Negros and Panay coastlines were more frequent than any other place in the entire archipelago. It is therefore safe to postulate that because of regular fracas, these ethnic groups honed their fighting skills and developed a more technical form of combat vis a vis the other regions. The Visayans dominance in the Filipino martial arts has nothing to do with boastfulness as what Pedro Reyes wrote in his article The Filipino martial tradition. For lack of a weighty hypothesis Pedro Reyes without qualms and understanding of the sensibilities of the proud Visayans insulted us:

"Arnisadores prefer teachers who shine by their own light, like the sun, rather than the planets that shine by the reflected light of their school or teacher. That is why arnisadores like Jose Caballero. (Ce buano) Remy Presas (Ilonggo) and Edgar Sulite(Waray) claim to have created their own styles, rather than to have inherited them. Incdentally, masters from the North are more apt to be self-deprecating while masters from the South are more prone to boast. This is due to social convention and personal dynamics and has little to do with actual ability. But in the country of hard sell this could be one reason why arnis from the south is spreading throughout the world, while arnis from the North remains in the shadows" 
Reading between the lines, it is another vain effort by people of the North to muddle the history of the Filipino martial arts. Reyes is no different from the pretentiou FMA historians out to skew the facts about the Filipino Martial Arts and as a loyal practitioner of Kali Ilustrisimo, in effect he is banging himself in the head or unless he will concoct a story that the Ilustrisimo system originated in Tondo or Ilocos.

I've always been a proud Cebuano, however I find it difficult to believe that Lapu-lapu defeated Magellan with his superior Kali skills as portrayed by the pseudo historians in the Filipino martial arts circles. For all I care Magellan could have tripped on the corals off the shores of Mactan and bashed his head on the rocks. The "battle" that took place as historians tell us was actually a lopsided massacre. Magellan only had less than a 50 man reconnaissance patrol (not a full scale invasion by any military standard) against more than one thousand men of Lapu-lapu, and you call that a martial art victory? Pure hogwash! As the first Asian to repel a foreig invader, Lapu-lapu's niche in Philippine history is already assured, but please let us stop spicing up the story on the "Battle" of Mactan as an epic display of our hero's Martial Arts prowess.

I have nothing against organizations calling their Art Kali, that is just fine for branding purposes, but laying claim that it is the mother of Eskrima / Arnis and that it originated in Muslim Mindanao is a contentious issue. Kali is a contradiction in terms, where can you find a practitioner of Kali who calls himself "Kalisado" or "Kalista"- no less than Grandmaster
Antonio Ilustrisimo prefered to be called an Eskrimador, or even our myopic friend Pedro calls himself an Arnisador. Master Ben Largusa leader of LargusaVillabrille Kali calls his late mentor Grandmaster Floro Villabrille an Eskrimador. Let us assume for the purposes of discussion that indeed Kali was practiced by the Te Kali was practiced by the Ten Datus of Panay as what Mark Wiley suggested in his book the Filipino Martial Arts:

"Legends claim that ten Datus (chieftains) left Borneo and settled in Panay where they established the Bothoan in the twelfth century. The Bothoan was a school where the Datus taught Kali along with academic subjects and arriculre. It was a kind of preparator school for tribal leaders."

But then again, as he said it is just a legend - told and retold and embellished for several generations that any scholar in his right mind would not take with a grain of salt. While we did have lectures about the Code of Maragtas and Kalantiaw,(which is already proven as a fake) I can't recall any of the history my teachers back in college mentioning a sophisticated system of combat like Kali during the pre-Hispanic period. Such a wonderful subject as an ancient Martial Art would have been a good piece of classroom discussion. So, how could our teachers miss that during those years when Bruce Lee's Eskrima exhibition in the movie Enter the Dragon was still very fresh in our memory. Again, granting that Bothoan really existed and Kali was one of the lessons in their curriculum . .well, what was true in 1500 s or prior to that, was not necesarilly true to other adjacent islands... no internet cafe then, no text messaging and no TransAsia plying the route.

I would like to argue that assumption of Mark Wiley by again quoting Paul Morrow:

"So, how do we tell what is true and what is false in Philippine history? Here is a rule of thumb: Any account that assigns an exact date to an event in the Philippines before the arrival of the Spanish in 1521 is probably not true. At present there is only one exception to that rule. That is the date recorded on the Laguna Copperplate Inscription of 900 A.D. which was proved by skilled investigation. As time goes on, more and more exceptions to the rule of thumb will arise due to the efforts of the increasing number of new historians who desire to correct the lies that were taught to Filipinos in the past."

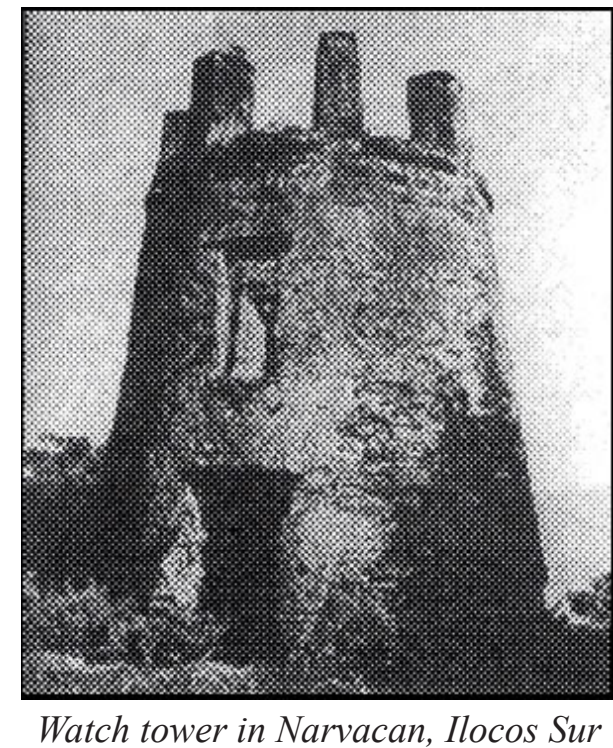

If indeed Kali is a very old term and has something to do with warriorship then everyone must be familiar with it like the words baraw, tameng, sondang, bangkaw .and it would have imprinted an indelible mark in the collective consciousness of the Visayan peo- ple for hundreds of generations like boundaries of Bukidnon, Davao the Moro bogeyman that our yayas (babysitters) used to scare to pacify our childhood tantrums: "Hala kon di ka mohilom dagiton ka sa Moros ug e-lawog sa Tirong" (Hey, if you won't shut up the Moro is going to snatch you and feed you to the Tirongs).

To muddle the issue furthe there are other amateur linguist in the Filipino martial arts that theorize on certain Visayan words as the root of Kali. They say that Kali is related to many words, that means that this same word has connections with the following Visayan words: Kalipay (Happiness), Kalibutan (Earth/World), Kalibog (Confusion), Kaliwat (Relatives/ Ancestors/Heredity), Kalisud (Difficulty), Kalibanga (Diarrhea/ LBM), Kalimotaw (Eye Pupil), Kaligo (Bath), Kalit (Sudden), Kalihim (Secretary) ... okay let us disarrange the letters ... Kilat (Thunder), Kilas (Agility) ... and where and when did kris become kalis? What language is that? Espe kalis?
ranto?

For twenty-two years I have traveled the entire breadth of Mindanao as a Salesman while on the side searching in vain for the vaunted Kali man I've read so much in Filipino martial arts books. Without luck, everywhere I went dodging bullets and 105-mm howitzers whistling past my ears, from Ipil, Zamboanga del Sur to

\section{Bibliography:}

"Cebu in Legend and History" by: Evangeline Lavilles de Paula

"Sumad: Essays for the Centennial of the Revolution in Cebu" by Erlinda Kintanar Alburo (Center for Cebuano Studies) "Angels in Stone" Pedro G. Galende, OSA

"Maragtas and Kalantiaw-History or Fraud?" by: Paul Morrow

"Pre-Hispanic Source Materials for the Study of Philippine History" by: William Henry Scott

"Swish of the Kris" by: Vic Hurley

"Complete Sinawali" by: Reynaldo Galang ogous to what we see in "Kali", Eskrima, or Arnis. Or maybe they really don't have any organized sword fighting system after all and relied purely on suicidal frenzy and the sharpness of their Kris at the height of mayhem. Knowing the typical Mindanao Muslim's penchant for announcing in huge streamers petty accomplishments such as passing the Teacher's Board Exams, their "sticker-happy" cars, gun-totting warlords and flamboyant display of jewelry,

Martial Art known as Kali that they supposedly invented can be kept secret until today.

So where does our theory on the origin of the first Filipino Martial Art fit in? Simple logic, given our hyphothesis:

- Years 1635-1644 The Explosion of FMA during the administration of Governor General Sebastian Hurtado de Corcuera

Recruitment of Pampango,

Cebuano, Ilonggo and Warays and cross pollination of raw martial skills with aid of Spanish fencers.

- Warrior priest actively en-

gaged in combat alongside Christian Indios and Spanish Regulars

Coined by no less than the Spanish colonial masters of the era, the single most definitive word that best described their engagement

with the indomitable Moros of
I find it incredible how such a

$$
\begin{aligned}
& \text { Silat and Kuntao are indig- } \quad \text { with the indomitable Mo } \\
& \text { to the Island of Basilan but }
\end{aligned}
$$


Special thanks to the following contributors: Mert Altares, King Fahd University of Petroleum \& Minerals, Dhahran, Saudi Arabia., Juris Fernandez, Liloan, Cebu

\section{Rapis \\ Joutrenal}

Research and Propagation for Internal Arts Development

The Rapid Journal was the No $\# 1$ martial arts magazine in the Philippines. Closing its doors in 2010, it still offers all the issues that came out. Get them before they run out.

For back issues of Rapid Journal visit: ( www.RapidJournal.com ) or ( www.berdugo.us )

\section{Interview with Celestino C. Macachor}

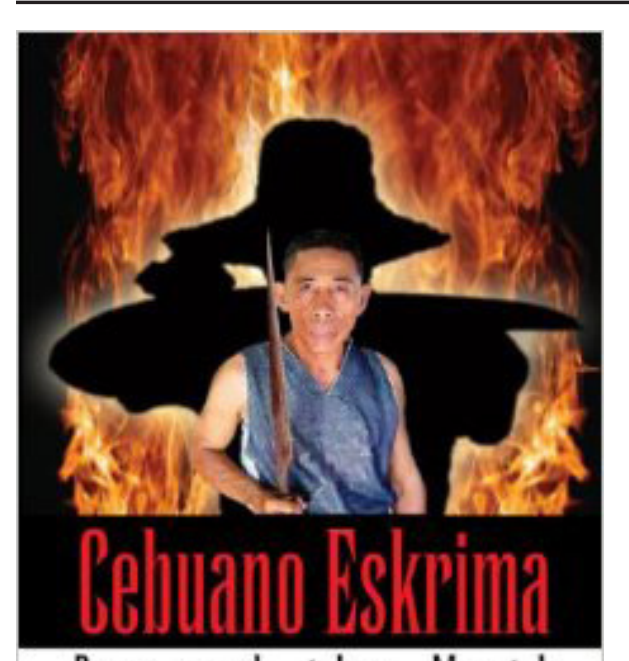

The book Cebuano Eskrima: Beyond the Myth - authored by Ned R. Nepangue, M.D. and Celestino C. Macachor is a must have book, if interested or wanting to know about the Filipino martial arts. Basically about Cebuano Eskrima it takes away a lot of fictional stories and brings facts to the table.

The FMA Informative representative met Ned Nepangue in 2008 while in Manila, Philippines and there was just a little conversation about a few things, due to time restraints. Mr. Nepangue was a very busy person researching some new material for the future.

However the FMA Informative while visiting the Philippines in 2015 and in Cebu as the representatives' first stop in the Philippines, was very fortunate to get to meet and talk with Celestino Macachor. It was an honor to finally meet with the co-author author of Cebuano Eskrima: Beyond the to finally

This time the FMA Informative representative was able to talk and disB e y o n I I t h e My I cuss somethings with Mr. Macachor on the subject of the Filipino martia arts about the past, present and future.

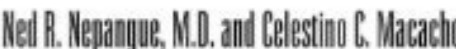

The FMA Informative is very appreciative to be able to ask $\mathrm{Mr}$. Macachor about the book he co-authored with Ned Nepangue which was published in 2007.

The book is divided into four parts:

Part One - is about Eskrima in genera

Part Two - is about Eskrima in Cebu

Part Three - covers some broad technical discussion on Eskrima

Part Four - includes extra notes related to Eskrima

The prologue lays out the idea and intentions of the book and the FMA Informative would like to quote some parts of it to the reader:

"The authors do not intend to present this book just like any other books on Filipino martial arts. This work is a reading material on Filipino culture where FMA is just but a small neglected part.

After decades of a "generic" description of Eskrima (a form of FMA), it is now the time to know more details. There is a need now for an in-depth study of the local or regional Eskrima perspectives and practices to appreciate Eskrima deeper."

"There is no "Cebuano Eskrima" as a system of Stickfighting the author's use this term for convenience to summarize all the systems and styles of martial arts considered traditional to Cebu in this book."

"This book is not an attempt to "demonize" the Moro people whom we highly esteem for their bravery in battle, but to present a more logical chronology of events based on historical facts, first-hand accounts by reliable resource persons, archaeological evidence and plain common sense on the true origins of Eskrima / Arnis / Estocada."

$------$

FMA Informative: How did it come about that you had the idea of writing And when did Mr. Nepangue become involved and did he come to you or you to him?

Mr. Macachor: Ned visited me for the first time in 1999 while I was still assigned in Ozamiz as Nestle Supervisor. He actually wanted to meet my elusive mentor Eric Olavides and was aware that he couldn't

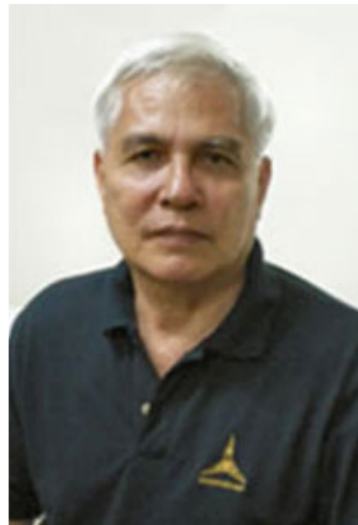
hook up with the latter if he can't get to me first. Ned saw me wearing a Kali T-shirt that I had printed a local shop. That's when he started to challenge me that kali, the supposedly mother of Filipino martial arts is a myth. Ned also tried to ajole me to write for the Rapid Journal Magazine, but I was hesitant at first because I never Eric Olavides had that much confidence in my writing skills. You know, I was such an underachiever back in high school and colleg sion in writing about the martial arts, I prefer to fight not write. Anger, Cebuano pride compelled me to once and for all write for the Rapid Journal magazine, when I read the late Pedro Reyes' article with a very condescending tone towards the Visayans. In one of his articles he said: "Arnisadores prefer teachers who light, like the sun, rather planets that shine by the reflected light of their school or teacher. That is why Arnisadores like Jose Caballero Remy Presas and Edgar Sulite claim to have created their own styles, rather than to have inherited them. Incidentally, Masters from the North are more apt to be self-deprecating while Masters from the South are more prone to boast. This is due to social convention and personal dynamics and has little to do with actual ability. But in the country of hard sell this could be one reason why Arnis from the south is spreading throughout the world, while Arnis from the North remains in the shadows".

He was actually shooting himself in the foot, considering his avowed reverence to his mentor a Ce- buano the legendary Antonio Ilustrisimo. I forgot the title of the article, but when it came out on the interthe editor of the Rapid Journal my open disgust and anger of this statement. I am a proud Cebuano, and I'd break anyone's head who'll say anything derogatory about the Cebuanos and the Visayans.

FMA Informative: Once getting started on the book, what was involved in deciding what would be in the book? And why?

Mr. Macachor: The book although titled Cebuano Eskrima, basically anchored on refuting the kali story. We tried to keep it as balanced as possible. Ned did most of the research on most of the history of the prominent clubs and personalities in Cebu Eskrima. Luck, Divine intervention, whatever you call it was on our side when we started on the book project. My Nestle colleague then MILO Sports Executive Pat Goc-ong told me of a legendary equestrian Eskrimador in southem Cebu by the name of Amby Kidlat who was the mentor his granduncle Felix "Titi" Goc-ong. Titi Goc-ong who once worked as a sacada in Hilo, Hawaii was deported back to the country for killing an African American in a juego todo duel. Felix Goc-ong passed on his Eskrima to Julian, Pat Goc-ong's father. All

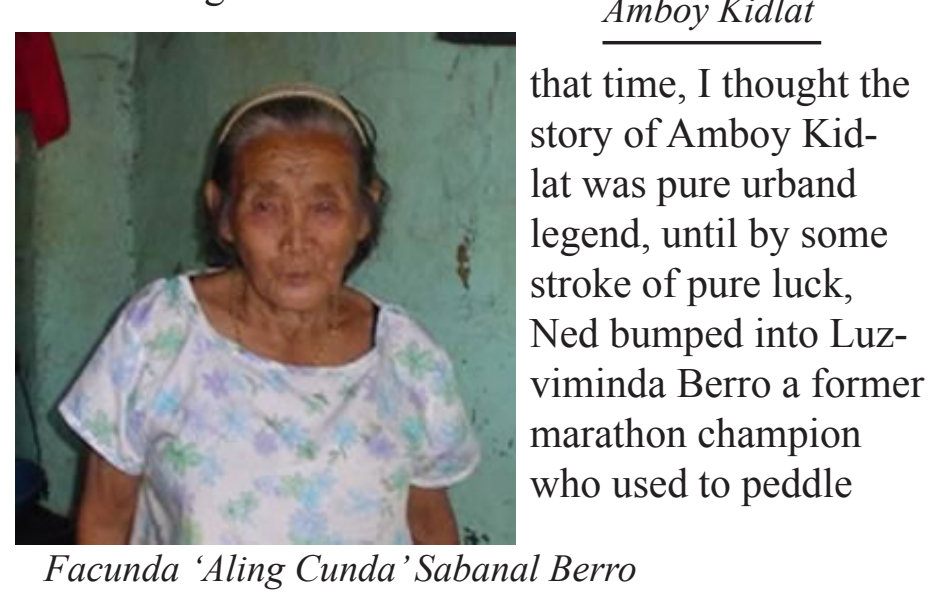

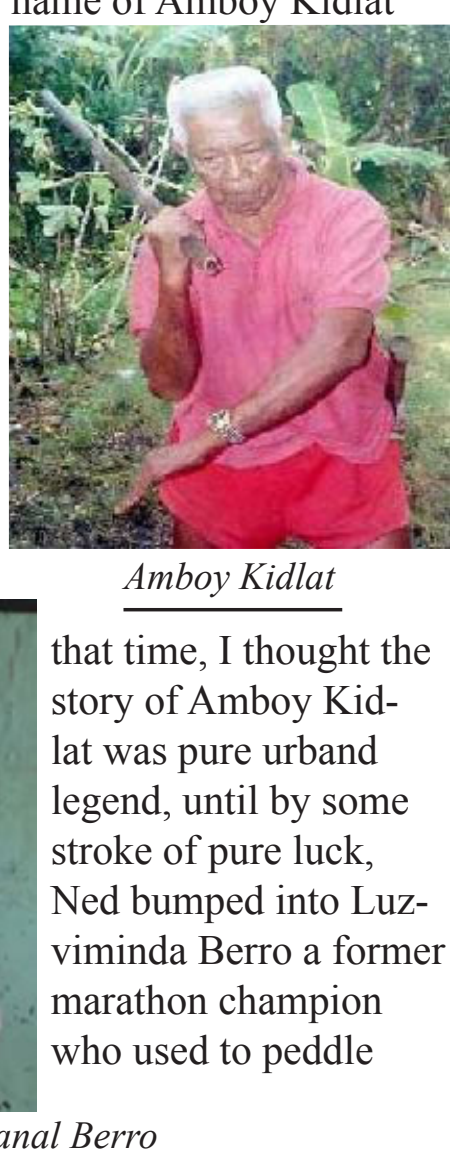



Amboy Kidlat. Lo and Behold, Luz is a granddaughte of Pablo "Amboy Kidlat" Sabanal. That's how we got to interview Aling Cunda Sabanal Berro, Amboy Kidlat's daughter and her eventual inclusion in the "|Lost Tribes" chapter.

FMA Informative: How long was the book in the works? How was the research conducted?

Mr. Macachor: It took us five years to complete the book and another year to get it published by Xlibris. We started working on it in 2001 sometime September when I was finally relocated by Nestle to my hometown Cebu City after 23 years in Mindanao. By that time I already had enough material, talked to a lot of people, from Muslim traders, blacksmiths in the interior and fringes Mindanao from Caraga, Cotabato, Bukidnon, Zamboanga Sibugay to find out about Kali which according to Dan Inosanto in his book "The Filipino Martial Arts" originated in Mindanao. The book was finally published in April 2007.

FMA Informative: Did you and Mr. Nepangue work on every aspect of the book together? Or was there sections that you worked on and Mr. Nepangue worked on other sections?

Mr. Macachor: We didn't follow a strict division of labor as far as content is concerned, whenever I cam up with an idea or Ned came up with his own, there was practically no argument or debate and we proceeded whatever we picked up. Except for one chapte "The Lost Tribes.. " where I wrote the entire content, of course with the materials and information Ned gathered. I guess $70 \%$ of the book was written by Ned, but I took care of the editing on the prologue and the epilogue, which was a very tedious process. It was like a ping pong game. After I was done with a portion of the book, I would mail it back to Ned and vice versa. Ned argued that Kali did not exist and it was herly influenced by the Spaniards. I plugged the holes and it was from one of my first article for the Rapid Journal where I presented a new hypothesis. If Kali tion, or did you and/or $\mathrm{Mr}$. on Nepangue consult various

my own research, and found out, that Spanish priests Mr. Macachor: Ned is very were responsible for the training of Visayans in the well versed on the technicalities of Eskrima, I gave him pacification of Sulu in Mindanao. Recently, there is a full credit for that by virtue of his having trained with the deluge of information shared to us by the gentlemen best instructors during his heyday like Jose "Joego" Miof HEMA (Historical European Martial Arts) especial-lan. You know very well I'm not a technique guy, I only ly Matt Galas of Belgium tons of materials of Spanish need to learn two or three strikes and that's all.

The FMA Informative would like to thank Mr. Macachor for his time and patience in answering the questions that were asked.

Mr Macachor and Mr Nepangue have put together a book that yes it has been out since 2007, however the FMA Informative believes that it was not handled correctly for maximum sales by the publisher, and has since it conception in 2011 promoted the sale of this book "Cebuano Eskrima: Beyond the Myth' in every FMA Informative newspaper and any other media that it has had the opportunity to advertise it

Many books that have come out in the past are not available in today's market. This book is still available, get it DO NOT make the mistake or the opportunity to have a book that will always be a piece of literary value and a treasure about the Filipino martial arts.

\section{Ned Nepangue Points out Some Facts on Kali}

We can only make a guess as to the origin of Eskrima/Arnis/ Estocada since there are no conclusive written records available in the archives to assist us in our research (that is, if we are really serious about this). Earlier writings did mentioned in passing, something regarding pre-Hispanic martial arts in the islands. But we should ats in the is, that the earliest Europeans who visited the islands did not know the native languages, were not familiar about the native culture at the time, were eth-

no-centrists, and were in the Orien primarily to look for spices and

not to do research on martial arts. Nobody can really say what kind of martial art these early travelers saw (if that was truly a martial art) when they first came that summe We cannot even say that it was Kali they saw, since they were no familiar about martial arts (like Draeger, Smith or Wiley). Let us also take note that during those times there was no unified form of government and people were not hooked in the Internet. People in the archipelago then (and this is still true until today) speak many languages, thus what was true in the island of Panay then, was not necessarily true in the nearby islands of Cebu or Samar. Forcing ourselves to believe that Eskri$\mathrm{ma} /$ Arnis/Estocada is something pre-Hispanic even without enoug proof to support the theory is not advisable.

We only have the following objective facts to help us prove or disprove the current theory of the origin of the Eskrima or Arnis.

Fact \#1: No written records available, which describes what this allegedly pre-Hispanic martial art of Kali really was and there is no vidence to prove that Eskrima/ Eskrima/ Arnis/Estocada martial arts

$$
\text { Earlier writings mentioned }
$$
how good those early natives were in hand-to-hand combat. These early European adventurers were maybe accurate in their appraisals since they were soldiers/fighters themselves and knew what was good form and what was not. But still the same, these available literatures do not give us details as to what kali really was. So kali can be everything, it can be stone throwing, wild boar hunting, yo-yo playing etc.

Fact \#2: Research found out that the natives in the islands before the Europeans came used shield and spears, weapons that are no longer visible in the majority of the contemporary Eskrima/Arnis/ Estocada schools.

If it is true that kali is the martial art practice by the ancient warriors in the islands then it must have included the use of the tameng or shield and the bangkaw spear. Since the art of Eskrima/ Arnis is derived from kali as some suggested then it must have these weapons includ weapons included in the curriculum. Tameng is still useful even in the modern times; in fact riot police are still using this contraption to control angry crowds. Spears on the other hand are still found in many other martial arts.

Fact \#3: The claims that historical personalities like Lapu Lapu, Tupas and others were really into kali or Eskrima remained unproven.

Some so-called authorities of the Filipino martial arts always associate names like that of Lapu Lapu to Eskrima, as if they were around already in 1500 s. The funny fact is they could not even provide atse (s) of years (in the 1600s, 1700, 1800s) to strengthen their claims. How one could claim he is the great-great grandson of the great Mr. So-andhis biological father is? 
Fact \#4: All Eskrima/Arnis share more common traits than differences.

The Filipino stick fighting in many ways is really different compared to other stick fighting systems in the region. The Eskrima styles as practiced by many Ilocanos in the far north of the archipelago are basically familiar to the styles found in the south, in the Visayas. There may be differences in some expressions but generally speaking they are the same.

Fact \#5: Practically all Eskrima systems/styles are practiced only in the Christianized groups (or those who are under the direct influence of the Spanish conquistadors for 333 years), and that no known Eskrima system/style is found among those peoples in the hinterlands of Luzon, among the Lumad and the Muslims in Mindanao.

The Spanish colonized the islands for 333 years, but they were not able to convert the entire population to the Christian faith. There were many ethnic groups left who were not directly controlled and influenced by them. Many of these groups are slowly assimilated still retain many of their pre-Hispanic practices. But if the theory is true that Eskrima and the like is something originally pre-Hispanic, then at least one of these many tribal groups could show us sampling of a functional Eskrima-like stick fighting art, but there is none.

Fact \#6: A link between Kali and Silat styles is yet to be proven,

both are really different in form and substance.

Many creative Eskrimador want to have this "Moro motif" integrated to their styles. In actuto do with the Muslims groups in he south who have their own very beautiful and lethal martial art of Silat. Many people foolishly attempted to establish link between the two, but until now they could not provide us enough evidence. In books and articles on eskrima they always include stories abo uramentado just to add dramatic effect, but in reality all of these, has nothing to do with Eskrima/ Arnis. Some insist that some of these Muslim tribes do practice some form of kali art. But if we inquire what tribe is that, they could not readily give answer. Some say it is in Sulu, but if we ask furthe which part of Sulu? Again there is no clear answer. Since the 70s when this claim first appeared, and until now nobody can really give the correct answer. Why? Well, the truth of the matter is, there is no kali in the Moroland. Just a pure fantasy. Is it possible to invent stories and fool the martial arts community? You bet! If you re familiar with the ef the Neolithic they reportedly found in Mindanao called Tasaday, you will easily understand how/why. In eskrima/arnis, emphasis is on weaponry first then unarmed fighting later, but in silat they have the weapons training only later.

Fact \#7: About $65 \%$ of technical terms used in all Eskrima/Arnis/ Estocada developed and propagated by many linguistically diverse ethnic groups are of Spanish origin.

The Spanish language was never totally adapted by the Filipinos unlike those in other former colonies of the North and South America. This was because the colonial authorities in the Philippines did not encourage the natives to learn the language. For three centuries, only the elite and the educated could speak an language. A strange fact is, a great percentage of technical terms used in Eskrima/Arnis/Estocada (and even the supposedly pre-Hispanic kali styles) are in Spanish, the language most Filipinos then (and now) did not speak. This is also the language used by the authorities who outlawed the practice and propagation of this native martial art. If the practitioners at that time were forced to practice in hiding, then why did they not use their own respective languages and dialects instead of using Spanish?

Fact \# 8: The connection between kali and Indonesian martial art of tjakalele is not yet proven.

Tjakalele is practically just a war dance originated in the Mollucas. It uses spears and shields, the weapons, which are not found in $99 \%$ of kali schools. Words like kali and tjakalele may sound familiar and related but this not proves anything that both are actually related.

Fact \#9: The suggestion that kali is the root word of some words found in different Filipino languages and dialects is not based on linguistics, in fact a study on this claim is yet to be made.

Important pre-Hispanic household words like diwata, Bathala, Datu, ulipon are still understood by many and this same is also true with words associated with the warriors, like bangkaw, baraw, tameng. So what is supposed to be the ancient name for the Filipino martial art? Kali? If it is kali then, why don't we find this word in dictionaries of the differen Filipino languages and dialects? In fact this particular word was just "re-introduced" years ago. Kali is never a traditional name for the native martial art. If one goes to a secluded place in Cebu for example and ask those Eskrima old-timers there if they know what is kali, the will probably say they don't know. And these people are supposed to know better.

Fact \#10: The earliest technical description about Eskrima/Arnis was available only lately.

The very first known book available in public was Yambao's book in 1957.

Fact \#11: Many modalities in Esrima/Arnis/Estocada like espada daga are also found in European fencing arts.

Fact \#12: The once Spanish colony of Venezuela in far-away South

America also have their own form of stick fighting.

The Garrote Larense stick fighting art of Venezuela reminds one of Eskrima. There must be a connection between these two martial arts somewhere and further research is needed.

Fact \#13: It is baseless to say that Eskrima or Arnis are just phases of the natural evolution of Kali that is Kali being the original form, Eskrima and Arnis the modern and diluted equivalents.

Kali that we can see today doesn't differ from Eskrima/A Some say that Kali is on blades while Eskrima/Arnis more on sticks implying that kali is more combative, realistic and original form while Eskrima/Arnis as sanitized intended for sports. But in places where the word kali is ot the traditional term used, the Eskrima/Arnis also included the practice of the bladed weapons. In fact many of those who categorize their styles as kali were actually erived from Escrima/Arnis

Fact \#14: There is no lack of good blacksmiths and is not the reason why many Escrima/Arnis fighters use sticks now instead of rea blades.

Many good Eskrimadors are not found in areas known fo their machete making skills. Many panday or sword smiths do not know Eskrima and it is never mentoned in the Philippine history that Philippines were running out of bolos.

Fact \#15: That the theory proposed is actually not corroborated in the works of the experts of the Philippine history, anthropology and sociology.

bal war was a re- ality especially before the island became a colony of Spain. When there is war, there are warriors, weapons and military arts. If kali was a military art then history books in high school and college must mention it. I do not remembe reading a word kali in our history books when I was still in high school and college, instead in our world history I read words like samurai, katana etc. Books of anthropology must also provide details about it. It is not mentioned, not because historians are not interested, it is simply because there is no sufficient information about it.

So basing on the aforementioned facts, we can only offer logical comments as to the possible origin of the contemporary Filipino martial arts (a bigger portion of which is the Eskrima/Arnis/ Estocada/Kali). It is basically a product of Filipino creativity and no doubt whatsoever, it is very Filipino. The bulk of its repertoire was developed during Spanish colonial times, and plausibly it got its inspiration from European fencing concepts and practices. It was greatly developed and refined (and the evolution still continues) only here in the islands of the Philippines.

\section{Cebu Eskrima Society \\ www.cebueskrima.s5.com}

The Cebu Eskrima Society's bold mission is to propagate and promote all indigenous Visayan Martial Arts of varying styles. It is not part of our mission to unify the various methods or systems but to find a common ground that we can nurture in order to stimulate enthusiasm of the Visayan Martial Arts and culture for future generations to inherit. It is only hrough our Martial Arts that we can find a distinct cultural identity, not our Christian traditions or Arroz Valenciana or Kinilaw or Otap or Paltik pistols. 


\section{School Submission}

The schools listed teach Filipino martial arts, either as the main curriculum or an added curriculum.

If you have a school that teaches Filipino martial arts, or you are an instructor that teaches, but does not have a school, list the school or style so individuals who wish to experience, learn and gain knowledge have the opportunity.

Be Professional; keep your contact information current. - Click Here

\section{Event Submission}

Submit your event whether - Seminar, Workshop, Training Camp, tournament, or Gathering - Click Here

\section{Advertisement Submission}

Advertising in the FMA Informative Website is FREE.

An Ad in the FMA Informative can create Business. Your Advertisement for Filipino martial arts forums, blogs etc, can be included in the FMA Informative. Advertisment is for the Filipino Martial Arts and the Philippines.

To submit Forums Click Here. To submit advertisement for products and/or Services Click Here

\section{Article Submission}

Finished manuscripts should be accompanied by color or black and white photographs. Though we take care of materials, we can not be responsible for manuscripts/photographs and accept no liability for same. Every photograph or graphic must be accompanied by a caption Carefully key photos to caption information with a letter or number.

We reserve the right to use any photo(s) as cover material or additional compensation. We also reserve the right to edit material and to crop photographs.

We reserve the right to use articles or parts of articles that are given and approved from time to time as needed to promote the Filipino martial arts and the Culture of the Philippines.

Physical manuscripts should be typed in black, double spaced, and set to 1-1/2 margins (right and left).

Emailed manuscripts should be typed in Ariel or Times Roman, on programs such as Notepad, Wordpad, Microsoft Word, Word Perfect and can be sent as an attachment. Photo(s) can be sent as a .jpg, .gif, .bmp, or .tiff - to submit material for either the FMA Informative Newspaper or an Issue Click Here

We welcome your article, ideas and suggestions, and look forward to working with you in the future. 